\title{
ECOLOGICAL BIOCHEMISTRY
}

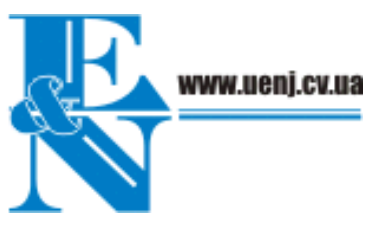

UDK 577.11:574.4

\author{
G. A. Ushakova $\square$ \\ H. N. Shiyntum
}

Dr. Sci. (Biol.), Professor

O. Honchar Dnipropetrovsk National University,

Gagarin ave, 72, Dnipropetrovsk, Ukraine, 49010

\section{EVOLUTIONARY PROGRESS IN THE FUNCTIONS OF METALLOTHIONEINS IN THE EVER CHANGING ECOSYSTEMS}

Abstract. Metallothioneins (MTs) exist in various organisms ranging from some prokaryotes to eukaryotes and mammals. MTs are low molecular weight proteins (MW ranging from 500 to $14000 \mathrm{Da}$ ), highly rich in cysteine residues and effectively bind with metals. MTs have the capacity to bind both physiological (such as zinc, copper, selenium) and xenobiotic (such as cadmium, mercury, silver, arsenic) heavy metals through the thiol group of its cysteine residues, which represent nearly $30 \%$ of its constituent amino acid residues. Their combination with heavy metals gives rise to metal-thiolate clusters. It has been suspected that the presence of cysteine in MT is necessary for its functioning and that MT itself is essential for life, modulating complex diseases and the immune system. All different types of MTs are classified with respect to so many factors mainly in groups I and II. There are four main distinguished sub families of the mammalian MT gene families; MT-1 (subtypes $A, B, E, F, G, H, L, M, X$ ), MT-2, MT-3, $M T-4$. They are synthesised primarily in the liver and kidneys. Their production is dependent on availability of the dietary minerals, as zinc, copper and selenium, and the amino acids histidine and cysteine. The rise of these sub families can be attributed to the different functions fulfilled by them. The absence of one defined primary common function could certainly be the reason for serial duplications that gave rise to the respective isoforms. The evolution of MT has been so important to science that they have been considered valid biomarkers in medicine and environmental studies. MT is not limited to the human system, it has also been found in other mammals of the animal kingdom vertebrates (such as the chicken, Gallus gallus, or the mammalian Mus musculus), in higher plants (such as Pisum sativum, Triticum durum, Zea mays, Quercus suber), in protozoa (ex. the ciliate Tetrahymena genera), in yeast (such as Saccharomyces cerevisiae, Candida albicans), in invertebrates (such as the nematode Caenorhabditis elegans, the insect Drosophila melanogaster, the mollusc Mytilus edulis, or the echinoderm Strongylocentrotus purpuratus and in many prokaryotes (such as the cyanobacteria Syneccococus spp). The MTs from this diverse taxonomic range represent a highheterogeneity sequence (regarding molecular weight and number and distribution of Cys residues) and do not show general homology; in spite of this, homology is found inside some taxonomic groups (such as vertebrate MTs).

In this review, we will be looking at the evolution of MTs in respective organisms and the different roles they perform in each of their respective locations in these organisms. We will specifically look at the following factors; evolution of the genetic constitution of MTs and their structural composition and functions.

Keywords: Metallothioneins (MTs), structure, classification, evolution, genes, function.

Tel.: +38063-273-81-03. E-mail: hnkafor@yahoo.com

DOI: $10.15421 / 031510$ 
Дніпропетровський національний університет ім. О. Гончара, пр. Гагаріна, 72, м. Дніпропетровськ, Украӥна, 49010, тел.: +38063-273-81-03, e-mail: hnkafor@yahoo.com

\section{ЕВОЛЮЦІЙНИЙ ПРОГРЕС У ФУНКЦІЯХ МЕТАЛОТІОНЕІНІВ У ЕКОСИСТЕМАХ, ЩО ПОСТІЙНО ЗМІНЮЮТЬСЯ}

Анотація. Металотіонеіни (МТ) $є$ в різних організмах, починаючи від деяких прокаріотів, до еукаріотів і ссавців. МТ є протеїнами 3 низькою молекулярною масою (в інтервалі від 500 до 14000 Да), збагачені на залишок цистеїну й ефективно зв'язуються 3 металами. МТ здатні зв'язувати як фізіологічні іони (наприклад, цинку, міді, селену), так і іони важких металів-ксенобіотиків (таких як кадмій, ртуть, срібло, миш'як) за рахунок тіолової групи своїх залишків цистеїну, які представляють близько 30 \% складу амінокислотних залишків. Їх зв'язування 3 важкими металами призводить до утворення металтіолових кластерів. Вважається, що присутність цистеїну в МТ необхідно для його функціонування, а також має важливе значення для виживання організмів, так як може змінювати імунний статус. Різні типи МТ класифіковані, головним чином, у групах I і II. Виділяють чотири основні підгрупи сімейства металотіонеінів, які поділяють залежно від сімейств генів МТ ссавців; MT-1 (підтипи А, В, Е, F, G, H, L, M, X), МТ-2, МТ-3, МТ-4. Вони синтезуються головним чином в печінці та нирках. Їхня продукція залежить від наявності харчових мінералів, таких як цинк, мідь і селен, і гістидину амінокислот і цистеїну. Підрозділ на багато підгруп МТ пов'язано з різними функціями даних білків. Відсутність однієї з певної первинної загальної функції, безумовно, може бути причиною для виділення відповідних ізоформ МТ в окремий підтип. Еволюція МТ дуже важлива для науки, так як віддзеркалює зміну спектру важливих біомаркерів в медицині та екологічних дослідженнях. МТ не обмежуються організмом людини, вони також знайдені в інших ссавців серед хребетних (наприклад, курки, Gallus Gallus, або ссавців Mus Musculus), у вищих рослин (наприклад, Pisum sativum, Triticum durum, Zea mays, Quercus suber), в найпростіших (напр. інфузорія Tetrahymena genera), в дріжджах (наприклад, Saccharomyces cerevisiae, Candida albicans), у безхребетних (наприклад, нематоди Caenorhabditis elegans, комах Drosophila melanogaster, молюсках Mytilus edulis, або голкошкірих Strongylocentrotus purpuratus і в багатьох прокаріотів (наприклад, ціанобактерії Syneccococus spp). МТ від такого різноманітного таксономічного діапазону є дуже неоднорідні (за молекулярною маси та кількості й розподілу залишків цистеїну), частіше всього мають низьку ступінь гомології; незважаючи на це, гомологія знаходиться всередині деяких таксономічних груп (наприклад, хребетних МТ).

У даному огляді розглянуто еволюцію МТ в різних організмах залежно від мінливості виконуваної функції даних білків за пристосування до конкретних умов проживання. В огляді акцентовано увагу на наступні фактори: еволюція генів МТ, структурна організація даних молекул, їх функції.

Ключові слова: металотіонеіни (MT), структура, класифікація, еволюиія, гени, функиія.
УДК 577.11:574.4
Г. А. Ушакова
д-р биол. наук, проф.
О. Н. Шиинтум

Днепропетровский национальный университет им. О. Гончара, пр. Гагарина, 72, г. Днепропетровск, Украина, 49010, тел.: +38063-273-81-03, e-mail: hnkafor@yahoo.com

\section{ЭВОЛЮЦИОННЫЙ ПРОГРЕСС В ФУНКЦИЯХ МЕТАЛЛОТИОНЕИНОВ В ПОСТОЯННО МЕНЯЮЩИХСЯ ЭКОСИСТЕМАХ}

Аннотация. Металлотионеины (МТ) имеются в различных организмах, начиная от некоторых прокариот, до эукариот и млекопитающих. МТ являются белками с низкой молекулярной массой (в интервале от 500 до 14000 Да), обогащены остатками цистеина и эффективно связываются с металлами. МТ способны связывать как физиологические ионы 
(например, цинка, меди, селена), так и ионы тяжелых металлов - ксенобиотиков (таких как кадмий, ртуть, серебро, мышьяк) за счет тиоловой группы своих остатков цистеина, которые представляют около $30 \%$ состава аминокислотных остатков. Их связывание с тяжелыми металлами приводит к образованию металтиоловых кластеров. Предполагают, что присутствие цистеина в МТ необходимо для его функционирования, а также имеет важное значение для выживаемости организмов, так как могут изменять иммунный статус. Различные типы МТ классифицированы, главным образом, в группах I и II. Выделяют четыре основных подгруппы семейства металлотионеинов, которые подразделяют в зависимости от семейств генов МТ млекопитающих; MT-1 (подтипы А, B, E, F, G, H, L, M, X), MT-2, МТ-3, МТ-4. Они синтезируются в основном в печени и почках. Их продукция зависит от наличия пищевых минералов, таких как цинк, медь и селен, и гистидина аминокислот и цистеина. Подразделение на множество подгрупп МТ связано с различными функциями данных белков. Отсутствие одной из определенной первичной общей функции, безусловно, может быть причиной для выделения соответствующих изоформ МТ в отдельный подтип. Эволюция МТ очень важна для науки, так как отражает изменение спектра важных биомаркеров в медицине и экологических исследованиях.

В данном обзоре рассмотрена эволюция МТ в различных организмах в зависимости от изменчивости выполняемой функции данных белков в условиях приспособления к конкретным условиям обитания. В обзоре акцентировано внимание на следующие факторы: эволюция генов МТ, структурная организация данных молекул, их функции. функичия.

Ключевые слова: металлотионеины (MT), структура, классификация, эволючии, гены,

\section{INTRODUCTION}

Evolution is change in heritable traits of biological populations over successive generations in the ecosystem. Evolutionary processes give rise to diversity at every level of biological organisation, including the level of species, individual organisms, and at the level of molecular evolution (Brian, 2011). The use of the name metallothionein was first mentioned in 1957 to describe a protein isolated from equine renal cortex containing large amounts of sulphur and cadmium (Margoshes \& Vallee, 1957; Kagi \& Vallee, 1960) and to date, there has been unraveling of more structures and functions implying that MTs evolution is equally a fast growing process. Metallothioneins are rich cysteine low molecular weight proteins that are said to be essential in the detoxification of the mammalian system. They are also said to be heat stable and metal binding (Margoshes \& Vallee, 1957).

The human body expresses at least ten known very closely related MT proteins. The production of MT is zinc and selenium dependent from dietary minerals as well as histidine and systeine present in the body. They are largely synthesized in the liver and the kidney in humans but are found at a number of other sites.

Its main functions are said to be the detoxification of metals (heavy metals in particular) like mercury and cadmium, the homeostasis of essential metals including Cupper and Zinc, anti-oxidation against reactive oxygen species, protection against DNA damage, oxidative stress, cell survival, angiogenesis, apoptosis, as well as increase proliferation, in the body (Higashimoto et al., 2009).

Since the discovery of MTs in 1957, many experiments have been carried out to date with different organisms. It has been found in many of these organisms that MTs exist in different locations and are very vital for the existence of these organisms. Most of these organisms embody many isoforms of these MTs and each has a function all though some of their roles have yet to be highlighted as are their mechanisms as well. Mammals, including humans, have four isoforms but the first two $(M T-1 / M T-2)$ had been known to be the major isoforms expressed ubiquitously by most mammalian organs including the brain (Cherian et al., 2003) but recent studies have identified $M T-3$ as the major metalloprotein in the brain and CNS (Egli et al., 2006). MT-4, although found in the squamous epithelial and also 
known to have life saving functions, is still to be studied on a large scale as have been the previous three.

In other organisms like insects, each of the studied type has its own distinguished MT features and functions. Some of the functions have been confirmed to be common in certain insects, like the predominance of MTs in the brain in the case of Drosophila melanogaster (four MTs), Orchesella cincta (one MT), and Oxya chinensis (two MTs) characteristically for protection against toxicity from heavy metals (Liu et al., 2014) but strangely, Oxya chinensis has also been found to contain a significant amount of MTs in the gut (Klaassen et al., 2009). As far as D. melanogaster is concerned, $M T-C$ and $M T-D$ have not yet been found to possess strong roles due to their inability to bind strongly with heavy metals.

\section{Metallothionein structure and classification}

MT is not limited to the human system, it has also been found in other mammals of the animal kingdom vertebrates (such as the chicken, Gallus gallus, or the mammalian Mus musculus), in higher plants (such as Pisum sativum, Triticum durum, Zea mays, Quercus suber), in protozoa (ex. the ciliate Tetrahymena genera), in yeast (such as Saccharomyces cerevisiae, Candida albicans), in invertebrates (such as the nematode Caenorhabditis elegans, the insect Drosophila melanogaster, the mollusc Mytilus edulis, or the echinoderm Strongylocentrotus purpuratus and in many prokaryotes (such as the cyanobacteria Syneccococus spp). The MTs from this diverse taxonomic range represent a highheterogeneity sequence (regarding molecular weight and number and distribution of Cys residues) and do not show general homology; in spite of this, homology is found inside some taxonomic groups (such as vertebrate MTs).

Fowler et al. were the first to establish a classification of MTs in 1987 into three classes; Class I was made to include polypeptides related in the positions of the Cys to equine MT-1B (MTs homologous to horse MT), Class II included MTs non homologous to horse MT, and Class III comprised phytochelatins, cys-rich enzymatically synthesized peptides (polyisopeptides composed of atypical gamma- glutamylcysteinyl units and are no therefore direct gene products) (Fowler et al., 1987). The second classification was performed by Binz and Kagi in 2001, and takes into account taxonomic parameters and the patterns of distribution of Cys residues along the MT sequence. It results in a classification of 15 families for proteinaceous MTs (Binz \& Kagi, 1999). Family 15 contains the plant MTs, which in 2002 were further classified by Cobbet and Goldsbrough into 4 Types (1, 2, 3 and 4) depending on the distribution of their Cys residues and a Cys-devoid regions (called spacers) characteristic of plant MTs.

MTs are classified base on the similarities of their structures. All mammalian MTs are placed Class I. The amino acids sequences of MTs of mammalian origin contain approximately 61 aa of similar composition. They all contain 20 cysteine residues that remain unchanged along the aa sequence. These systeines participate in the coordination of $7 \mathrm{~mol}$ of $\mathrm{Cd}$ or $\mathrm{Zn}$ per mol of MT, explaining why they have a high affinity for $\mathrm{Cd}\left(10^{-22}\right)$ and $\mathrm{Zn}\left(10^{-18}\right)$ (Kagi \& Vallee, 1960).

In mammals, 20 totally conserved cysteine residues (Cys) bind, in the reduced form, a complement of 7 equivalents of polarizable bivalent metal ions giving rise to two unique metal-thiolate clusters with characteristic spectroscopic features (Binz \& Kagi, 1999). The spontaneous refolding of the native structure upon metal addition attests to a guiding role of the positions of the Cys and other AAs conserved in the polypeptide chain. The invertebrate holo-MTs studied thus far display similar clusters with structural and compositional variations due to different numbers and relative positions of the Cys residues on the polypeptide chain.

Table below shows how much MTs in various ecosystems have marginally evolved. The characterization and structurization of MT have been revealed by only a few articles. Its three dimensional structure was first reported by X-ray crystallography and NMR spectroscopy in the 1990s. Later structural studies have shown that MT with 61aa can bind 


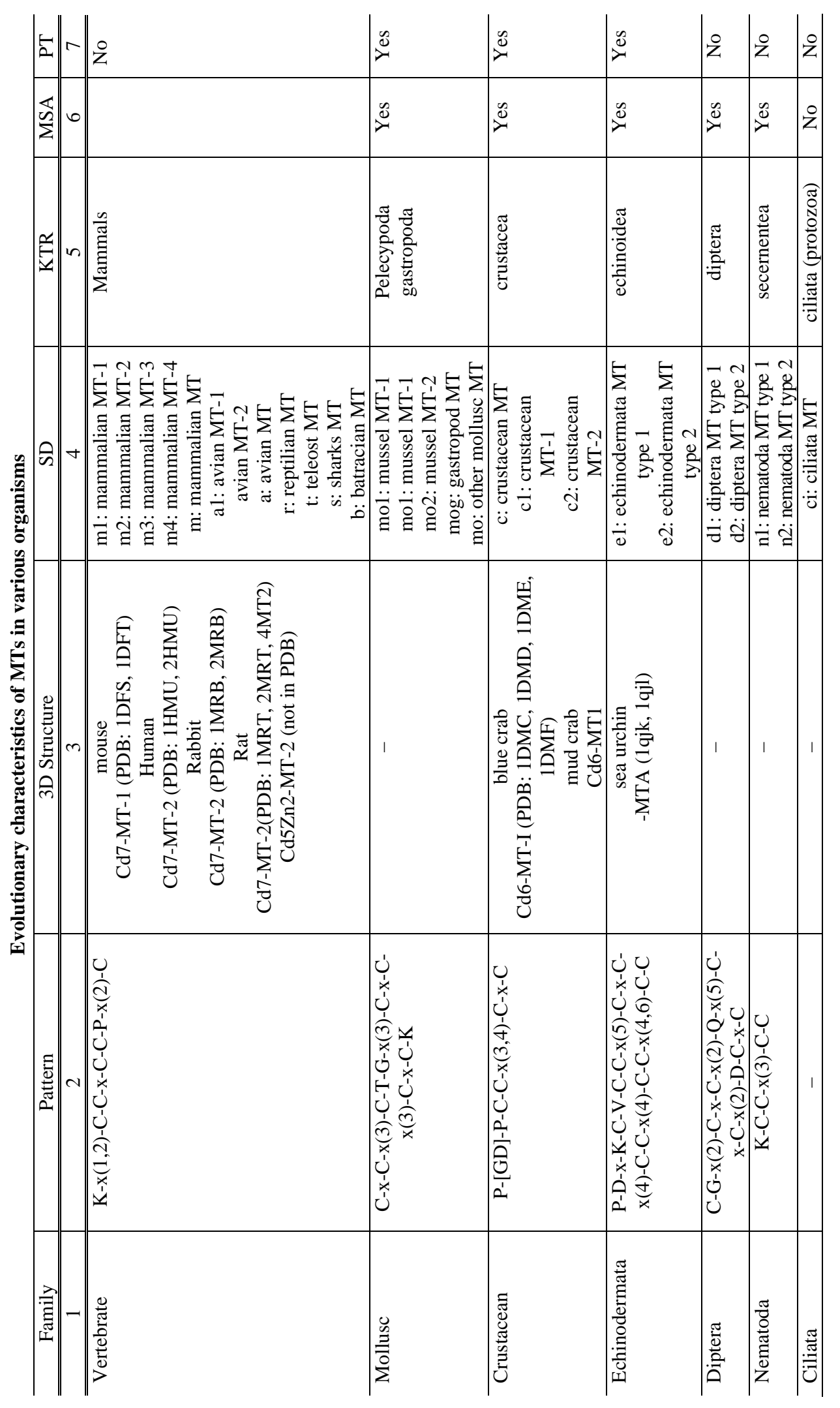




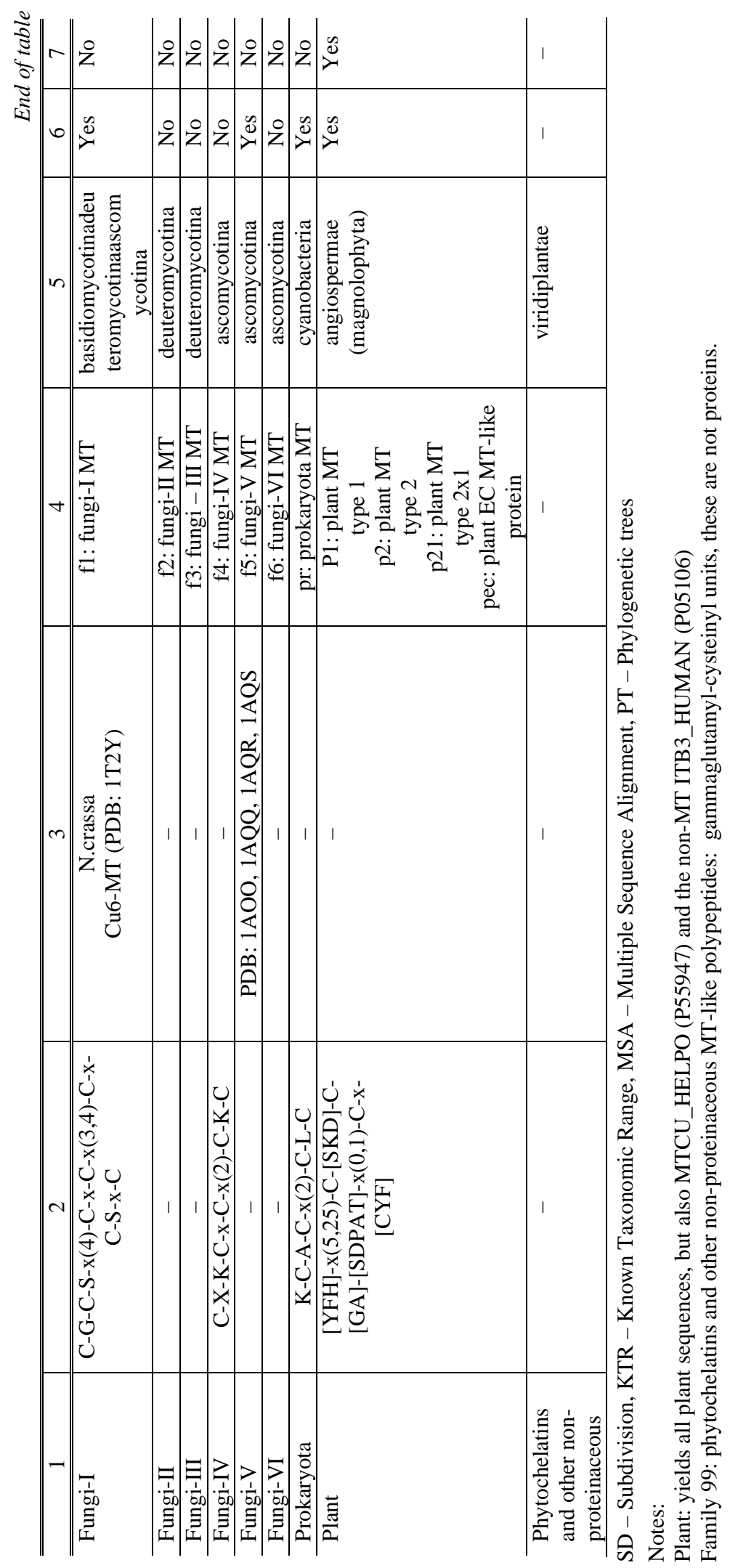




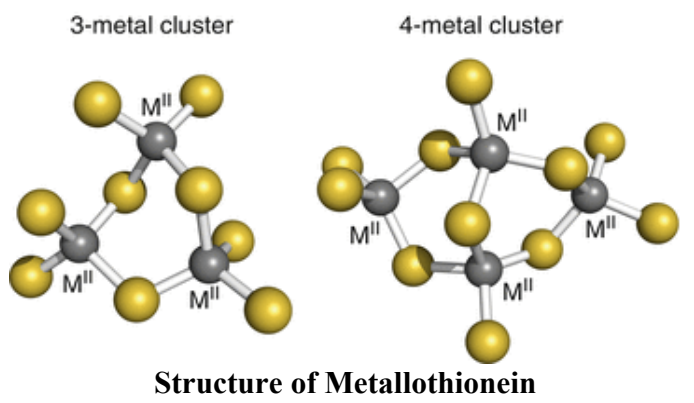

with both essential (Zinc and Copper) and toxic (Cadmium and Mercury) metals in two distinct cluster within the molecule. One cluster is closer to the N-terminal and three metal atoms bound structures to nine cysteines with three bridging sulphur atoms, while the second cluster is closer to the C-terminal and four metal atoms bound to 11 cysteines with five bridging sulphur atoms figure (Schicht \& Freisinger, 2009).

\section{Specific Functions of MTs}

Metallothioneins have been found to exist in various tissues of different species, ranging from eukaryotes to mammals, playing significant roles in their respective locations for the life of the individuals. MTs are stress proteins that bind with metals and regulate the homeostasis of essential trace metals, counteracting the toxic effects of heavy metals such as $\mathrm{Cd}, \mathrm{Hg}$ and $\mathrm{Ag}$ in insects (Viarengo et al., 1999). Looking at the different types of MTs and their functions in different organisms will portray a manner of evolution that has captured the attention of a huge audience of the scientific world in modern times.

MTs and their functions have been studied in insects such a Drosophila melanogaster, Orchesella cincta, and Oxya chinensis with some similar and very dissimilar patterns of distribution and function. D. melanogaster has four MTs (MT-A, MT-B, MT-C, MT-D), all of which are transcriptionally induced by heavy metals through the same metal-responsive transcription factor, MTF-1 (Egli et al., 2006), while Orchesella. cincta has only one identified MT. Two MTs (OcMT-1 and OcMT-2) have recently been identified in Oxya chinensis (Liu et al., 2014).

MTs B, C, D are located in the same gene cluster and encode very similar peptides (67\% amino acid identity) (Egli et al., 2003). Drosophila MT-A and MT-B were classified as copper-type thioneins due to their metal binding properties. (Valls et al., 2000; Domenech et al., 2003). The expression of MTs at the gene level is transcriptionally regulated by metal-responsive transcription factor 1 (MTF-1), homolog to the mammalian MTF-1. The mechanism is such that MTF-1 binds to the short DNA motifs termed metalresponsive elements (MREs) in the MT promoter upon metal load. These MREs are necessary and sufficient to mediate the transcriptional response to heavy metals (Stuart et al., 1984). Basal and induced levels of transcription in both mammals and in Drosophila depend on MTF-1 activity, and consequently a mutation of MTF-1 in both organisms dramatically increases the sensitivity to heavy metals (Egli et al., 2003, Wang et al., 2004). $M T-A$ and $M T-B$ are of major importance to the heavy metal defense of Drosophila, with a leading role of $M T-A$ and $M T-B$ for $\mathrm{Cu}$ and $\mathrm{Cd}$ load respectively. Individual activities of MTs are achieved by the corresponding specificity in induction and, probably some metalcluster features that confer a more optimal character to the $C u-M T-A$ and $C d-M T-B$ complexes, respectively (Egli et al., 2006). This has been shown already for MT-B under high cadmium load (Domenech et al., 2003). The roles played by $M T-C$ and $M T-D$ are still to be well elucidated as their metal-binding capacity is very insignificant as compared with the capacity of $M T-A$ and $M T-B$.

The two MTs obtained from $O$. Chinensis possessed different coding sequences, peptides and cysteine concentrations (11). The amino acid sequence of OcMT1 protein was similar in length to those of $M T-A, M T-B, M T-C$ and $M T-D$ in Drosophila, varying from 
40aa to 44aa (Egli et al., 2003) and are much shorter than the MTs of most other species, ranging in size from 58aa to 61aa. Both OcMT1 and OcMT2 code for most of the conserved cysteine residues and functional motifs such as (C-C, C-X-C, C-X-Y-C) (10). A total of 16 cysteine residues were found along the entire OcMT2 sequence, and cysteine and lysine (Lys, K) were adjacent at four positions. The Cys residues adjacent to Lys have been suggested to play roles in the structures and stabilities of the metal-binding sites of the protein (Chung et al., 1991). These important structural characteristics suggest that OcMT1 and OcMT2 may be involved in heavy metal detoxification by capturing the metal within the tissues and that these residues may serve as primary chelating sites (Ren et al., 2010). The two OcMT genes were found to be widely expressed in the brain, the optic lobe and the digestive tissues (FG, GC, MG and HG) (Liu et al., 2014). The expressions levels of OcMT1 and OcMT2 in the fat bodies were higher compared with those in the other tissues with the exception of the brain and optic lobe. These findings suggest that OcMT1 and OcMT2 can detoxify exogenous chemicals. The higher expression levels of OcMT2 in the ovaries suggest that this MT may be related to the protection of $O$. chinensis reproduction from metal toxicity or from oxidative stress (Klaassen et al., 2009). Therefore, the two MTs may play important roles in the detoxification of exogenous chemicals (Liu et al., 2014).

Mammalian MTs are mainly consisted of MT-1, MT-2, MT-3, and MT-4. They originated through a series of duplication events. In a general sense, MT-1 and MT-2 encode for ubiquitous proteins while $M T-3$ and $M T-4$ evolved to accomplish specific roles in the brain and epithelium respectively. Further expansion of the MT-1 gene has occurred in the primate lineage reaching in humans a total of 13 paralogs, five of which are pseudogenes, while the remaining eight are still functionally active. In humans, the reading frame of all five MT-1 pseudogenes is reconstructed by sequence homology with a functional duplicate revealing that loss of invariant cysteines is the most frequent event accounting for pseudogeneisation. Expression analyses based on EST counts and RT-PCR experiments show that, as for MT-1 and MT-2, human MT-3 is also ubiquitously expressed while MT-4 transcripts are present in brain, testes, esophagus and mainly in thymus (Moleirinho et al., 2011).

Mammalian MT-1 and MT-2 are conserved proteins that play a critical role in heavymetal homeostasis and are transcriptionally induced by metal (Beach \& Palmiter, 1981) and glucocorticoids (Hager \& Palmiter, 1981).

Since its discovery (Palmiter et al., 1992), MT-3 has been frequently associated with the protection against neuronal injury (Chung \& West, 2004; Hozumi et al., 1995). The mammalian MT3 protein shows a characteristic insertion of six residues at the a-domain when compared to that of MT-1 and MT-2 and an extra residue in the b domain (Thr), which is responsible for neuron growth inhibitory activity in Alzheimer disease (Cai et al., 2006; Romero-Isart et al., 2002). Although the expression of MT-3 has been almost exclusively related to brain tissues, it has also been demonstrated that $M T-3$ is a ubiquitously expressed gene. In this regard, it is worth mentioning that MT-3 associates with other proteins in mouse brains as part of a multiprotein complex (Lahti et al., 2005) suggesting function diversification and involvement in various physiological processes.

MT-4 retains a high degree of conservation between humans and mice, yet it shows the highest sequence divergence when compared with any other MT family member (Moleirinho et al., 2011). It has been shown that mouse Mt-4 retains the capacity to bind $\mathrm{Zn}$ (Quaife et al., 1994; Tio et al., 2004), $\mathrm{Cd}$ and $\mathrm{Cu}$ as the ubiquitously expressed MT-1/MT-2, although the affinity to $\mathrm{Cu}$ is higher (Tio et al., 2004, Meloni et al., 2006). Suggestions have been made that MT-4 is inactive in some individuals (Moleirinho et al., 2011). It is tempting to assume that the loss (pseudogeneization) of MT-4 can be compensated by functional equivalents. In this context, $M T-1$ and $M T-2$ would be the most likely candidates for a number of reasons. First, the metal binding properties of $M T-1$ and $M T-2$ overlap that of MT-4 in mice (Cai et al., 2005). Second, it has been demonstrated that some MT-1 duplicates have cellular specificity (Schmidt \& Hamer, 1986; Cherian et al., 2003) and some of them are expressed in epithelium. Third, previous experiments in Drosophila 
melanogaster demonstrated that the number of functional gene duplications correlates to the resistance to $\mathrm{Cd}$ (Maroni et al., 1987; Maroni et al., 1986) and $\mathrm{Cu}$ (Maroni et al., 1987) as a direct consequence of the increased gene expression.

\section{CONCLUSION}

There exist a general consensus as to the principal functions of MTs; detoxification and homeostasis, but the common impression is that we are still a long way from seeing the end of their evolution. As the various ecosystems continue to evolve, so do every micro and macro components in the ecosystems. Many isoforms and sub-isoforms from various organisms have been identified but most functions are yet to be attributed to a lot of them. A very common factor about the MTs is that they are triggered by the presence of heavy metals, enabling homeostatic, detoxification and oxidative stress functions. From the time of their discovery till today, MTs have evolved massively with the latest researches being carried out to find treatment for various diseases especially in the battle against cancer. At the rate at which their evolution continues to unravel via experiments, it is only a matter of time before many functions are figured out and their uses are expanded.

\section{REFERENCES}

Beach, L. R., Palmiter, R. D., 1981 Amplification of the metallothionein-I gene in cadmium-resistant mouse cells. P Natl Acad Sci USA, 78, 2110-2114.

Binz, P. A., Kagi, J. H. R., 1999. Metallothionein: molecualar evolution and classification. Advanced Life Sciences, 7-13.

Brian, K. H., 2011. Strickberger's Evolution. Jones \& Bartlett Publishers. Dalhousie University Brian K Hall, PH.D.; Benedikt Hallgrímsson. ISBN 978-1-4496-4722-3. pp. 3-6.

Cai, B., Zheng, Q., Huang, Z-X., 2005. The properties of the metal-thiolate clusters in recombinant mouse metallothionein- 4 . Proteins 24, 327-336.

Cai, B., Zheng, Q., Teng, X-C., Chen, D., Wang, Y., Wang, K. Q., Zhou, G. M., Xie, Y., Zhang, M. J., Sun, H. Z., Huang, Z. X., 2006. The role of Thr5 in human neuron growth inhibitory factor. J Biol Inorg Chem, 11, 476-482.

Cherian, M. G., Jayasurya, A., Bay, B. H., 2003. Metallothioneins in human tumors and potential roles in carcinogenesis. Mutat Res, 533, 201-209.

Chung, R. S., West, A. K., 2004. A role for extracellular metallothioneins in CNS injury and repair. Neuroscience, 123, 595-599.

Chung, W. P., Dewan, J. C., Walters, M. A. 1991. Models of lysine-cysteine hydrogen bonding in metallothionein: hydrogen bodnfing between ammonium and benzenthiolate in $\left[\left(\mathrm{C}_{6} \mathrm{H}_{11}\right)_{2} \mathrm{NH}_{2}\right]^{2}\left[\mathrm{Co}\left(\mathrm{SC}_{6} \mathrm{H}_{5}\right)^{4}\right]$. J Am Chem Soc, 113, 525-530.

Domenech, J., Palacios, O., Villareal, L. Gonzalez, D. P., Capdevila, M., Adrian, S., 2003. MTO: the second member of a Drosophila dual copperthionein system. FEBS Lett, 533, 72-78.
Egli, D, Domenech, J., Selvaraj, A. Balamurugan, K., Hua, H., Capdevila, M., Georgiev, O., Schaffner, W., Atrian, S., 2006. The four members of the Drosophila metallothionein family exhibit distinct yet overlappig roles in heavy metal homeostasis and detoxification. Genes Cells, 11, 647-658.

Egli, D., Selvaraj, A., Yepiskoposyan, H., Zhang, B., Hafen, E., Georgiev, O., Schaffner, W., 2003. Knockout of metal-responsive transcription factor MTF-1 in Drosophila by homologous recombination reveals its central role in heavy metal homeostasis. Embo J, 22(1), 100-108.

Fowler, B. A., Hildebrand, C. E., Kojima, Y., Webb M., 1987. Nomenclature of metallothionein. Experientia Suppl, 52, 21.

Gumulec, J., Raudenska, M., Adam, V., Kizek, R., Masarik, M., 2014. Metallothionein immunohistochemical Cancer Biomarker: a meta-analysis. PLoS ONE 9(1):e85346. doi:10.1371/journal.pone.0085346.

Hager, L. J., Palmiter, R. D., 1981. Transcriptional regulation of mouse liver metallothionein-I gene by glucocorticoids. Nature 291, 340-342.

Hahn, Y., Lee, B., 2006. Human-specific nonsense mutations identified by genome sequence comparisons. Hum Genet 119, 169-178.

Higashimoto, M., Isoyama, N., Ishibashi, S., Inoue, M., Takiguchi, M., Suzuki, S., Onishi, Y., Sato, M., 2009. Tissue dependent preventive effect of metallothionein against DNA damage in dyslipidemic mice under repeated stresses of fasting or restraint. Life Sciences, 84, 569-575.

Hozumi, I., Inuzuka, T., Hiraiwa, M., Uchida, Y., Anezaki, T., Ishiquro, H., Kobayashi, H., Uda, Y., Miyatake, T., Tsuji, S., 
1995. Changes of growth inhibitory factor after stab wounds in rat brain. Brain Res, 688, 143-148.

Kagi, J. H., Vallee, B. L., 1960. Metallothionein, a cadmium and zinc containing protein from equine renal cortex. J Biol Chem, 235, 3460-3465.

Klaassen, C. D., Liu, J., Diwan, B. A., 2009. Metallothionein protection of cadmium toxicity. Toxicol Appl Pharm 238, 215-220.

Lahti, D. W., Hoekman, J. D., Tokheim, A. M., Martin, B. L., Armitage, I. M., 2005. Identification of mouse brain proteins associated with isoform 3 of metallothionein. Protein Sci, 14, 1151-1157.

Liu, Y., Wu, H., Kou, L., Liu, X., Zhang, J., Guo, Y., Ma, E., 2014. Two metallothionein genes in Oxya chinensis: molecular characteristics, expression patterns and roles in heavy metal stress. PLoS ONE 9(11):e112759.doi:10.1371/journal.pone.0112759.

Margoshes, M., Vallee, B. L., 1957. A cadmium protein from equine kidney cortex. J Am Chem Soc, 79, 4813-4814.

Maroni, G., Otto, E., Young, J. E., 1986. Structure and expression of a tandem duplication of the Drosophila metallothionein gene. P Natl Acad Sci USA, 83, 6025-6029.

Maroni, G., Wise, J., Young, J. E., Otto, E., 1987. Metallothionein gene duplications and metal tolerance in natural populations of Drosophila melanogaster. Genetics 117, 739-744.

Meloni, G., Zovo, K., Kazantseva, J., Palumaa, P., Vasak, M., 2006. Organization and assembly of metal-thiolate clusters in epithelium-specific metallothionein-4. J Biol Chem, 281, 14588-14595.

Moleirinho, A., Carneiro, J., Matthiesen, R., Silva, R. M., Amorim, A., Azevedo, L., 2011. Gains, losses, and changes of function after gene duplication: study of the metallothionein family. PLoS ONE, 6(4):e18487. doi:10.1371/journal.pone.0018487.

Palmiter, R. D., Findley, S. D., Whitmore, T. E., Durnam, D. M., 1992. MT-III, a brainspecific member of the metallothionein gene family. P Natl Acad of Sci USA, 89, 6333-6337.

Quaife, C. J., Findley, S. D., Erickson, J. C., Froelick, G. J., Kelly, E. J., Zambrowicz, B. P., Palmiter, R. D., 1994. Induction of a New Metallothionein Isoform (MT-IV) Occurs during Differentiation of Stratified Squamous Epithelia. Biochemistry-US, 33, 7250-7259.
Ren, F., Jiang, H., Sun, J., He, L., Li, W., Wang, Y., Wang, Q., 2010. Cloning, characterization, expression, and copper sensitivity of the metallothionein-1 gene in the Chinese mitten crab, Eriocheir sinensis. Mol Biol Rep, 38, 2383-2393.

Romero-Isart, N., Jensen, L. T., Zerbe, O., Winge, D. R., Vasak, M., 2002. Engineering of Metallothionein-3 Neuroinhibitory Activity into the Inactive Isoform Metallothionein-1. J Biol Chem, 277, 37023-37028.

Schicht, O., Freisinger, E., 2009. Spectroscopic characterization of Cicer arietinum metallothionein 1. Inorg Chim Acta, 362, 714-724.

Schmidt, C. J., Hamer, D. H., 1986. Cell specificity and an effect of ras on human metallothionein gene expression. P Natl Acad Sci USA, 83, 3346-3350.

Stuart, G. W., Searle, P. F., Chen, H. Y., Brinster, R. L., Palmiter, R. D., 1984. A 12base-pair DNA motif that is repeated several times in metallothionein gene promoters confers metal regulation to a heterologous gene. P Natl Acad Sci USA, 81, 7318-7322.

Tio, L., Villarreal, L., Atrian, S., Capdevila, M., 2004. Functional differentiation in the mammalian metallothionein gene family: metal binding features of mouse MT4 and comparison with its paralog MT1. J Biol Chem, 279, 24403-24413.

Tokuda, E., Ono, S-I., Ishige, K, Naganumad, A., Ito, Y., Suzuki, T., 2007. Metallothionein proteins expression, copper and zinc concentrations, and lipid peroxidation level in a rodent model for amyotrophic lateral sclerosis. Toxicology, 229, 33-41.

Valls, M., Bofill, R., Romero-Isart, N., Gonzalez-Duarte, R., Abian, J., Carrascal, M., Gonzalez-Duarte, P., Capdevila, M., Atrian, S., 2000. Drosophila MTN: a metazoan copperthionein related to fungal forms. FEBS Lett. 467(2-3), 189-194.

Wang, Y., Wimmer, U., Lichtlen, P., Inderbitzin, D., Stieger, B., Meier, P. J., Hunziker, L., Stallmach, T., Forrer, R., Rulicke, T., Georgiev, O., Schaffner, W., 2004. Metal-responsive transcription factor-1 (MTF-1) is essential for embryonic liver development and heavy metal detoxification in the adult liver. FASEB J. 18,1071-1079. 